\title{
АНАЛІЗ АСОРТИМЕНТУ ЛІКАРСЬКИХ ЗАСОБІВ ГЕМОСТАТИЧНОЇ ДІЇ
}

Вступ. 3 огляду на мінливість фрармацевтичного ринку, економічної та політичної ситуації в країні, аналіз асортименту антигеморагічних лікарських засобів дозволяє виявити фрактори, що впливають на надання фрармацевтичної допомоги хворим, і напрями покращення фрізічної та економічної доступності препаратів даного сегмента.

Мета дослідження - вивчити асортимент антигеморагічних засобів, які представлені на вітчизняному фрармацевтичному ринку, та виявити місце препаратів рослинного походження.

методи дослідження. Асортимент лікарських засобів і динаміку продажу вивчали за допомогою доступних електронних ресурсів та аналітичних систем.

Результати й обговорення. Визначено, що структура асортименту сфрормована лікарськими засобами групи В02 "Антигеморагічні засоби". Аналіз зареєстрованих лікарських препаратів за окремою діючою речовиною показав, що в цій групі максимальну частку становлять засоби, які містять фрактори згортання крові й транексамову кислоту. Встановлено країни, що експортують на українськии фрармацевтичнииринок антигеморагічні лікарські засоби. Визначено основних вітчизняних виробників досліджуваного асортименту лікарських засобів. При сегментації ринку препаратів за лікарськими фрормами встановлено перевагу парентеральних фрорм. Антигеморагічні засоби рослинного походження займають лише 12,5 \% від загального асортименту.

Висновок. Проведені дослідження дають підстави стверджувати, що розробка лікарських препаратів на основі рослинної сировини кровоспинної дії є перспективною та необхідною.

КЛЮЧОВІ СЛОВА: антигеморагічні засоби; аналіз асортименту; фармацевтичний ринок гемостатиків.

ВСТУП. Гемостаз - це система захисту організму від кровотечі при порушенні цілісності стінки судини. Система гемостазу включає тканини, що оточують судину, стінку судини, плазмові фрактори згортання, фрормені елементи крові.

Класифрікація порушень гемостазу включає 3 показники. За походженням розрізняють спадкові та набуті, за механізмом розвитку - порушення судинно-тромбоцитарного і коагуляційного гемостазу, за спрямованістю змін виділяють гіпо- та гіперкоагуляцію.

Гіпокоагуляція - зниження здатності крові згортатися 3 появою схильності до повторних кровотеч та крововиливів (спонтанних чи після незначних травм).

Під кровотечею (haemorrhagia) розуміють витікання крові з ушкодженої судини в тканини, порожнини організму, зовнішнє середовище. Причиною кровотечі $є$ порушення цілісності судинної стінки, яке можуть викликати травма, (с) У. В. Карпюк, В. С. Кисличенко, 2017. арозія судини при різних гнійних і патологічних процесах, підвищення артеріального тиску в судині, різке зниження атмоссрерного тиску та інші фрактори.

Травма є досить частою причиною порушення цілісності судинної стінки, однак підвищена її проникність для крові може бути зумовлена змінами хімізму самої крові, дією токсинів, порушенням обміну вітамінів та ін. Кровотечі можуть виникати також внаслідок порушення згортання крові, в результаті дії деяких лікарських речовин $[1,2]$.

Препарати групи В02 "Антигеморагічні засоби" рекомендовано для лікування порушень гемостазу відповідно до стандартів і клінічних протоколів надання медичної допомоги хворим зі спеціальностей "Гематологія", "Хірургія", а також стандартів при наданні екстреної медичної допомоги, при аномальних маткових кровотечах $[3,4-7]$.

Гемостатичні засоби рослинного походження, як правило, прискорюють згортання крові й 
мають помірну кровоспинну дію. Їх призначають для зменшення кровотеч при геморагічних діатезах, гемороїдальних, носових, легеневих, ниркових, маткових та кишкових кровотечах [8].

Маркетинговим дослідженням антигеморагічних лікарських засобів (ЛЗ) вітчизняного фрармацевтичного ринку вже були присвячені роботи в різні періоди [9-13]. 3 огляду на мінливість фрармацевтичного ринку, економічної та політичної ситуації в країні, аналіз асортименту антигеморагічних лікарських засобів дозволяє виявити фрактори, що впливають на надання фрармацевтичної допомоги хворим, і напрями покращення фізічної та економічної доступності препаратів даного сегмента.

Мета дослідження - вивчити асортимент антигеморагічних засобів, які представлені на вітчизняному фрармацевтичному ринку станом на грудень 2016 р., та виявити місце препаратів рослинного походження.

МЕТОДИ ДОСЛІДЖЕННЯ. ТеоретичниЙ арсенал досліджуваних ЛЗ вивчали з використанням контент-аналізу Державного реєстру готових ЛЗ, Державного фрормуляра ЛЗ, результатів Дослідницької компанії "Моріон", Компендіуму станом на грудень 2016 р. Динаміку продажу препаратів рослинного походження вивчали за даними аналітичної системи дослідження срармацевтичного ринку "Pharm-Xplorer"/“Фармстандарт" компанії "Proxima Research".

РЕЗУЛЬТАТИЙ ОБГОВОРЕННЯ. На першОму етапі аналізу офріційних джерел інсрормації про зареєстровані та дозволені до медичного застосування в Україні лікарські засоби антигеморагічної дії сорормовано інформаційний масив 364 лікарських препаратів без урахування фрорм випуску і дозування [3, 14, 15].

Під час структурного та внутрішньогрупового аналізу відповідно до Міжнародної системи класиффікації ЛЗ (анатомо-терапевтично-хімічна класифікація) встановлено, що досліджувані ЛЗ належать до другої анатомічної групи В "Засоби, що впливають на систему крові та гемопоез" і складають другу терапевтичну групу В02 "Антигеморагічні засоби".

Анатомічна група В02 "Антигеморагічні засоби" представлена двома підгрупами 3-го рівня: В02A "Інгібітори фрібринолізу" і В02В "Вітамін К та інші гемостатичні засоби".

Тож структура асортименту ссрормована двома підгрупами: В02А та В02В. Серед них провідну позицію займає підгрупа В02В "Вітамін К та інші гемостатичні засоби", на яку припадає 58 \% від загального асортименту групи 2-го рівня В02 "Антигеморагічні засоби". Відповідно, на підгрупу В02А "Інгібітори фрібринолізу" припадає 42 \% від загального асортименту.

Серед підгрупи В02A "Інгібітори фрібринолізу" переважає підпідгрупа В02А А "Амінокислоти" 23 препарати або 36 \% від загального асортименту групи В02 "Антигеморагічні засоби" та 85 \% асортименту підгрупи В02А "Інгібітори фрібринолізу". В підгрупі 3-го рівня В02В "Вітамін К та інші гемостатичні засоби" препаратами-лідерами $€$ B02B D “Фактори згортання крові”. Вони займають 28 \% від загального асортименту групи В02 "Антигеморагічні засоби" та $48 \%$ асортименту підгрупи В02А "Інгібітори фрібринолізу".

Тож найбільшу питому вагу із загального асортименту групи В02 "Антигеморагічні засоби" мають підпідгрупи В02А А "Амінокислоти" - 36 \% та B02B D "Фактори згортання крові" - $28 \%$ (табл.).

Аналіз складу показав, що препарати групи В02 "Антигеморагічні засоби" $€$ переважно однокомпонентними (89 \%), тоді як частка комбінованих становить лише 12 \% і представлена переважно комбінаціями оракторів згортання крові.

Результат аналізу, в площині пропозицій лікарських препаратів за окремою діючою речовиною, свідчить про максимальну частку препаратів транексамової кислоти (23\%).

Таблиця - Розподіл лікарських засобів у групі В02 “Антигеморагічні засоби”

\begin{tabular}{|c|c|c|c|c|}
\hline \multicolumn{2}{|c|}{ Класифрікаційна категорія } & $\begin{array}{c}\text { Кількість } \\
\text { зареєстрованих }\end{array}$ & $\begin{array}{c}\text { Питома вага } \\
\text { зареєстрованих }\end{array}$ & $\begin{array}{c}\text { Кількість } \\
\text { препаратів }\end{array}$ \\
\hline \multirow{2}{*}{$\begin{array}{l}\text { В02А “Інгібітори } \\
\text { фрібринолізу" }\end{array}$} & В02А А "Амінокислоти" & 23 & 36 & 17 \\
\hline & В02А В “Інгібітори протеїназ” & 4 & 6 & 3 \\
\hline \multirow{4}{*}{$\begin{array}{l}\text { В02B "Вітамін К та } \\
\text { інші гемостатичні } \\
\text { засоби" }\end{array}$} & В02В А "Вітамін К" & 2 & 3 & 2 \\
\hline & $\begin{array}{l}\text { В02В С “Гемостатичні засоби } \\
\text { для місцевого застосування" }\end{array}$ & 2 & 3 & 1 \\
\hline & $\begin{array}{l}\text { В02B D “Фактори згортання } \\
\text { крові" }\end{array}$ & 18 & 28 & 10 \\
\hline & $\begin{array}{l}\text { В02B X "Інші гемостатичні } \\
\text { засоби для системного } \\
\text { застосування" }\end{array}$ & 15 & 24 & 14 \\
\hline \multicolumn{2}{|l|}{ Разом } & 64 & 100 & 47 \\
\hline
\end{tabular}


Слід відмітити, що на ринку присутні 73 \% препаратів гемостатичної дії від зареєстрованих, серед сракторів згортання крові - тільки 55 \% від зареєстрованих.

На наступному етапі вивчали асортимент зареєстрованих антигеморагічних засобів за ознакою країни-виробника. Відповідно до Державного реєстру лікарських засобів України, із 64 зареєстрованих препаратів, що належать до групи В02 "Антигеморагічні засоби" без урахування форми випуску та дозування, 32 виробляють в Україні. Інші 32 препарати, що представлені на фрармацевтичному ринку України, виготовляють іноземні виробники.

За результатами аналізу структури асортименту антигеморагічних засобів, встановлено, що серед 64 препаратів сегмента Л3 вітчизняного виробництва становлять $50 \%$ асортименту і представлені переважно у підгрупах В02B X "Інші гемостатичні засоби для системного застосування" - 86 \% та В02А А "Амінокислоти" - 60 \% (рис. 1). Крім того, за кількістю засобів, які виробляють у межах однієї країни, Україна посідає перше місце.

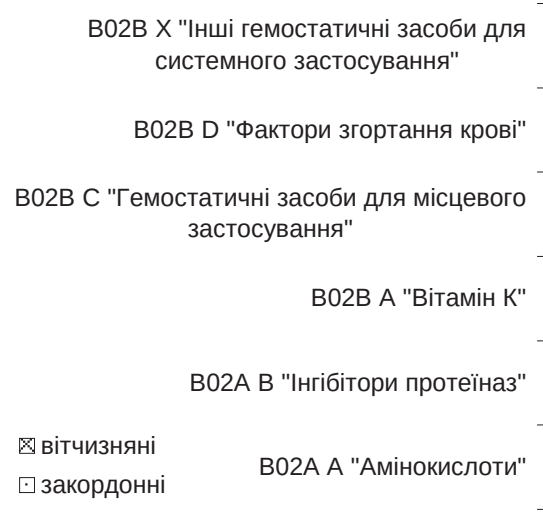

02B X "Інші гемостатичні засоби для
системного застосування" B02B D "Фактори згортання крові" $\square$ закордонні В02А А "Амінокислоти"
Асортимент кровоспинних засобів вітчизняного виробництва забезпечують 19 виробників. Серед них позицію лідерів за кількістю представлених препаратів займають ТОВ "ЮріяФарм", засоби якого становлять майже $13 \%$ або 4 препарати загального асортименту антигеморагічних засобів вітчизняного виробництва (рис. 2), та ПрАТ "Фармацевтична фрірма “Дарниця" і ПрАТ "ФФ "Віола" по 3 препарати або по 9 \% від зареєстрованих засобів.

Більшість інших вітчизняних виробників кровоспинних засобів представляє на ринку 1 або 2 препарати без урахування дозування та фрорм випуску.

Крім вітчизняних постачальників, 32 препарати кровоспинної дії на фрармацевтичному ринку України репрезентують іноземні виробники 314 країн ствіту: Австрії, Індії, США, Італії, Швейцарії, Кіпру, Російської Федерації, Угорщини, Чеської Республіки, Бельгії, Німеччини, Іспанії, Данії, Словенії (рис. 3). Відсутні зареєстровані препарати виробників з Китаю, Єгипту, Кореї, Великої Британії [9, 11]. Серед них незмінно найбільшу кількість засобів антигеморагічної дії

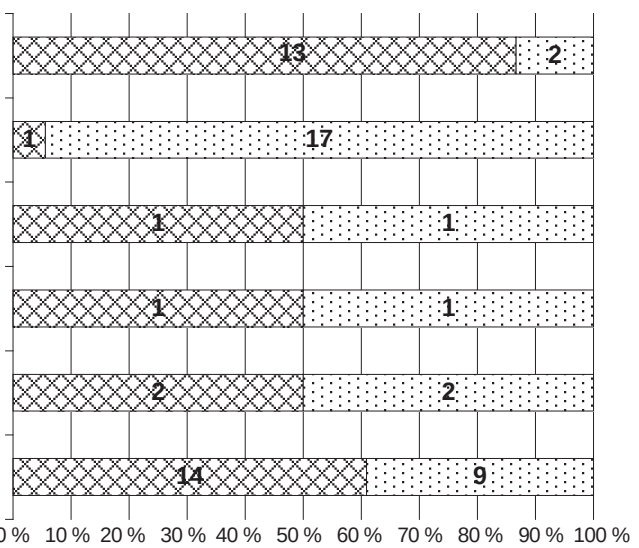

Рис. 1. Співвідношення зареєстрованих Л3 закордонного і вітчизняного виробництва.

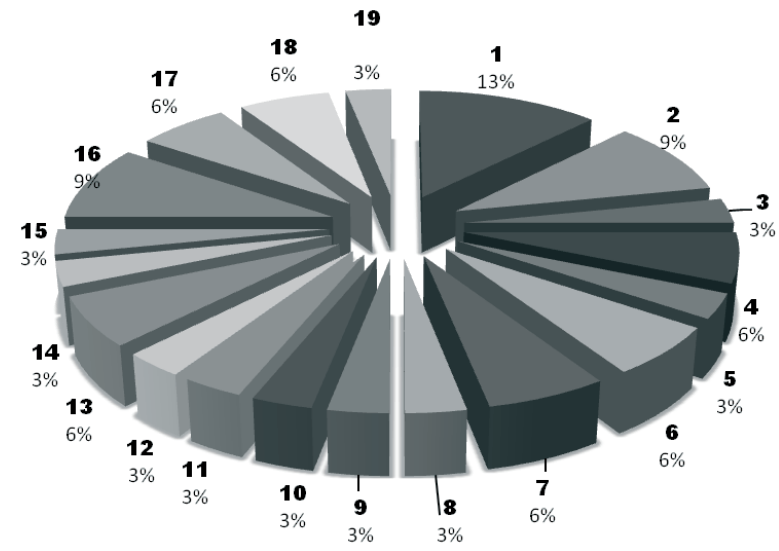

Рис. 2. Розподіл вітчизняних фрірм-виробників залежно від обсягу представлених на українському фрармацевтичному ринку зареєстрованих препаратів антигеморагічної дії: 1 - ТОВ "Юрія-Фарм"; 2 - ПрАТ “Фармацевтична фрірма “Дарниця"; 3 - ТОВ "Новофарм-біосинтез”; 4 - ТОВ "Ніко”; 5 - ЗАТ “Інфузія"; 6 - ТОВ “Фармацевтична компанія "Здоров'я"; 7 - ПАТ “Фітофрарм"; 8 - ТОВ “Фарм-інновації”; 9 - ПАТ “Фармак”; 10 - ПАТ “Галичфрарм"; 11 - ТОВ "Тева Україна”; 12 - ТОВ “Ф3 Біофрарма"; 13 - ТОВ “Біофрарма Плазма"; 14 - ТОВ "ФФ "Вертекс"; 15 - ПАТ “Київський вітамінний завод"; 16 - ПрАТ "ФФ "Віола"; 17 - ТОВ “Терносрарм"; 18 - ПрАТ “Ліктрави"; 19 - ТОВ "Дослідний завод "ГНЦЛС”. 
репрезентують компанії “Октасрарма” (Австрія) 4 препарать та "Бакстер" (Австрія) - 4 препарати $[9,11]$. Більшість інших іноземних виробників кровоспинних засобів представляє на ринку 1 або 2 препарати без урахування дозування та форм випуску.

При сегментації ринку препаратів кровоспинної дії за лікарськими фрормами було встановлено, що основна кількість препаратів представлена у вигляді парентеральних фрорм (43 препарати): розчини для ін'єкцій/інфузій, порошки для розчину та порошки ліофілізовані для розчину для ін'єкцій/інфрузій, що становлять $67 \%$ асортименту. Інша частина асортименту сегмен- та антигеморагічних засобів представлена такими фрормами, як: розчин, порошок для орального застосування, таблетки, таблетки, вкриті оболонкою, суха речовина, пластина, вкрита оболонкою, екстракт рідкий, листя/трава в пачці (рис. 4).

Залишається незмінною відсутність лікарських фрорм для педіатрії $[9,11]$.

Також слід відмітити, що деякі лікарські засоби надходять на ринок під однією торгівельною назвою від декількох виробників, тобто спостерігають ефект "дублювання асортименту".

Необхідно зазначити, що сегмент ринку, який аналізують, переважно представлений Л3 син-

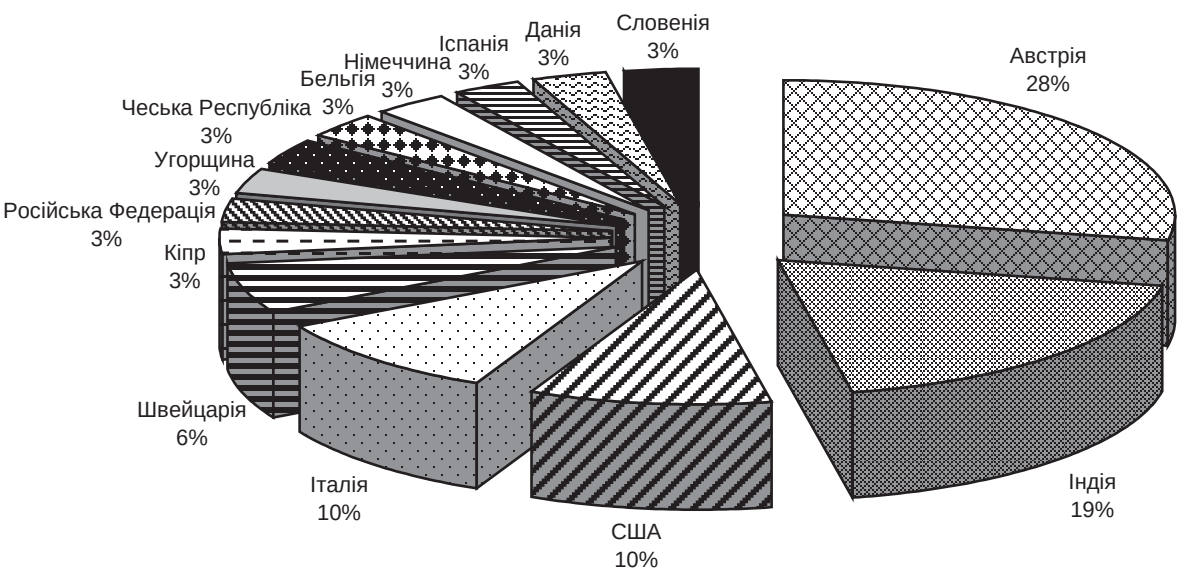

Рис. 3. Розподіл іноземних фірм-виробників залежно від обсягу представлених на українському фрармацевтичному ринку зареєстрованих препаратів антигеморагічної дії.

В02B X "Інші гемостатичні засоби для системного застосування"

B02B D "Фактори згортання крові"

В02В С "Гемостатичні засоби для місцевого застосування"

В02В А "Вітамін К"

В02А В "Інгібітори протеїназ"

В02А А "Амінокислоти"
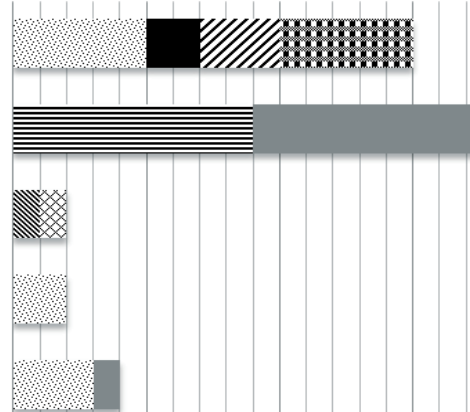

- розчин

$\approx$ порошок для орального застосування

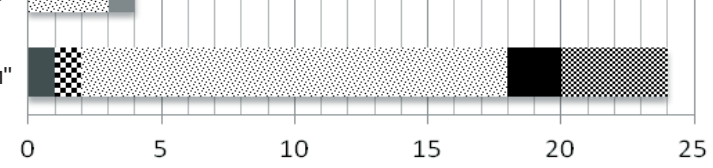

\% розчин для ін'єкцій/інфузій

- таблетки

жаблетки, вкриті оболонкою

三 порошок для розчину для інфрузій/ін'єкцій

- порошок ліофрілізований для приготування розчину для інфузій/ін'єкцій

ㄴ. суха речовина

× пластина, вкрита оболонкою

". екстракт рідкий

* листя/трава в пачці

Рис. 4. Розподіл зареєстрованих препаратів антигеморагічної дії за фрормами випуску. 
тетичного походження, лише підгрупа В02B X "Інші гемостатичні засоби для системного застосування" складається майже на 60 \% з рослинних препаратів.

"Гемостатичні засоби рослинного походження" В02В Х06** належать до підпідгрупи В02В X "Інші гемостатичні засоби для системного застосування". Асортимент В02В Х06** "Гемостатичні засоби рослинного походження" складають 8 препаратів із 64, він становить 12,5 \% у групі 2-го рівня В02 “Антигеморагічні засоби". У підгрупі 3-го рівня В02В "Вітамін К та інші гемостатичні засоби" на "Гемостатичні засоби рослинного походження" В02В Х06*夫 припадає майже $22 \%$ - це 8 препаратів із 37 (табл.). Асортимент В02В Х06** "Гемостатичні засоби рослинного походження" в Україні включає в себе: перцю водяного екстракт рідкий, кропиви листя, деревію траву. Ці засоби мають гемостатичну дію та системне призначення $[14,15]$.

Проведений частотний аналіз показав, що за частотою продажу гемостатичні засоби рослинного походження (перцю водяного екстракт рідкий, деревію трава) є одними з лідерів [10]. Крім того, за даними аналітичної системи "Pharm-Xplorer"/“Фармстандарт”, препарати В02В Х06** "Гемостатичні засоби рослинного походження" у 2016 р. зайняли перше місце за обсягами реалізації препаратів даного сегмента в натуральному виразі.

ВИСНОВКИ. 1. Проведений аналіз, у площині пропозицій зареєстрованих лікарських препа- ратів за окремою діючою речовиною, показав, що в групі В02 “Антигеморагічні засоби” максимальну частку становлять препарати, які належать до амінокислот (36 \%) та фракторів згортання крові (28 \%).

2. Результат аналізу, в площині пропозицій лікарських препаратів за окремою діючою речовиною, свідчив про максимальну частку препаратів транексамової кислоти (23 \% від загального асортименту).

3. Асортимент кровоспинних засобів вітчизняного виробництва забезпечують 19 виробників. На фрармацевтичному ринку України препарати кровоспинної дії репрезентують іноземні виробники з 14 країн світу.

4. При сегментації ринку препаратів кровоспинної дії за лікарськими формами було встановлено, що основна кількість препаратів представлена у вигляді парентеральних форм. Залишається незмінною відсутність лікарських фрорм для педіатрії.

5. Антигеморагічні засоби рослинного походження становлять лише 12,5 \% від загального асортименту, хоча засоби рослинного походження у 2016 р. зайняли перше місце за обсягами реалізації препаратів даного сегмента в натуральному виразі. Це свідчить про потребу препаратів рослинного походження кровоспинної дії.

6. Проведені дослідження дають підстави стверджувати, що розробка лікарських препаратів на основі рослинної сировини кровоспинної дії є перспективною та необхідною.

\section{СПИСОК ЛІТЕРАТУРИ}

1. Фармацевтична енциклопедія / голова ред. ради В. П. Черних. -2-ге вид., переробл. і допов. -К. : Моріон, 2010. - 1632 c.

2. Loscalzo J. Thrombosis and hemorrhage [Text] / J. Loscalzo, A. I. Schafer. - Lippincott Williams \& Wilkins, $-2003 .-1142$ p.

3. Державний фрормуляр лікарських засобів. - К., 2016. - Вип. 8. - 1076 с.

4. Про затвердження стандартів та клінічних протоколів надання медичної допомоги зі спеціальності “Хірургія" : наказ МОЗ України від 02.04.2010 p. № 297 [Електронний ресурс]. - Режим доступу : http:// www.moz.gov.ua/ua/portal/dn_20100402_297.html.

5. Про затвердження та впровадження медико-технологічних документів зі стандартизації медичної допомоги при аномальних маткових кровотечах : наказ МОЗ України від 13.04.2016 р. № 353 [Електронний ресурс]. - Режим доступу : http://www.moz.gov.ua/ ua/portal/dn_20160413_0353.html.
6. Про затвердження та впровадження медико-технологічних документів зі стандартизації екстреної медичної допомоги : наказ МОЗ України від 15.01.2014 р. № 34 [Електронний ресурс]. - Режим доступу: http://www.moz.gov.ua/ua/portal/dn_20140115_ 0034.html.

7. Про затвердження клінічних протоколів надання медичної допомоги хворим зі спеціальності “Гематологія" : наказ МОЗ України від 30.06.2010 р. № 647 [Електронний ресурс]. - Режим доступу : http://www. moz.gov.ua/ua/portal/dn_20100730_647.html.

8. Интегрированная фрармакология / К. Пейдж, М. Кертис, М. Уокер, Б. Хоффрман ; пер. с англ. ; под ред. Б. К. Романова. - М. : Логоссрера, 2012. $744 \mathrm{c}$.

9. Гудзенко О. П. Маркетинговий аналіз вітчизняного ринку антигеморагічних препаратів / О. П. Гудзенко, К. В. Кулдиркаєва // Вісн. фрармації. - 2009. № 4 (60). - С. 64-67. 
10. Кулдиркаєва К. В. Інтегрований ABC/VEN/ частотний аналіз споживання гемостатичних лікарських засобів в рамках регіонального ринку / К. В. Кулдиркаєва // Укр. мед. альм. - 2009. - 12, № 5. С. 105-107.

11. Маркетингові дослідження вітчизняного ринку антигеморагічних лікарських засобів / С. А. Куценко, В.В.Малий, А. Б. Ольховська, Ю. С. Маслій // Social pharmacy in health care. - 2016. - 2, № 3. - P. - 65-74.

12. Ярних Т. Г. Аналіз асортименту антигеморагічних лікарських засобів на вітчизняному фармацевтичному ринку / Т. Г. Ярних, О. І. Рубан, А. Б. Ольховська // Менеджмент та маркетинг у складі сучасної

\section{REFERENCES}

1. Chernykh, V.P. (2010). Farmatsevtychna entsyklopediia [Pharmaceutical Encyclopedia]. Kyiv: Morion [in Ukrainian].

2. Loscalzo, J., \& Schafer, A.I., (2003). Thrombosis and haemorrhage. Lippincott Williams \& Wilkins, 1142 p.

3. Derzhavnyi Formuliar likarskykh zasobiv [The State Formulary of medicines of Ukraine]. (2016). Vyp. 8, Kyiv [in Ukrainian].

4. Nakaz MOZ vid 02.04.2010 № 297 "Pro zatverdzhennia standartiv ta klinichnykh protokoliv nadannia medychnoi dopomohy zi spetsialnosti "Khirurhiia" [Order of Ministry of Health of 02.04.2010 No 297 "On approval of clinical protocols and standards of care in specialty "Surgery"]. Retrieved from: http://www.moz.gov.ua/ua/ portal/dn_20100402_297.html [in Ukrainian].

5. Nakaz MOZ Ükrainy vid 13.04.2016 № 353 "Pro zatverdzhennia ta vprovadzhennia medyko-tekhnolohichnykh dokumentiv zi standartyzatsii medychnoi dopomohy pry anomalnykh matkovykh krovotechakh" [Order of Ministry of Health of Ukraine of 13.04.2016 No 353 "On approval and introduction of medical and technological documents for standardization of medical care for abnormal uterine bleeding]. Retrieved from: http:// www.moz.gov.ua/ua/portal/dn_20160413_0353.html [in Ukrainian].

6. Nakaz MOZ Ukrainy vid 15.01.2014 № 34 "Pro zatverdzhennia ta vprovadzhennia medyko-tekhnolohichnykh dokumentiv zi standartyzatsii ekstrenoi medychnoi dopomohy" [Order of Ministry of Health of Ukraine of 15.01.2014 No 34 "On approval and introduction of medical and technical documents to standardize emergency medical care"]. Retrieved from: http://www.moz. gov.ua/ua/portal/dn 20140115 0034.html [in Ukrainian].

7. Nakaz MOZ Ükrainy vid 30. 06. 2010 № 647 "Pro zatverdzhennia klinichnykh protokoliv nadannia medychnoi dopomohy khvorym zi spetsialnosti "Hematolohiia" [Order of Ministry of Health of Ukraine of 30.06.2010 No 647 "On approval of clinical protocols of medical care in the specialty "Hematology"]. Retrieved from: http://www.moz.gov.ua/ua/portal/ dn 20100730 647.html [in Ukrainian].

8. Peydzh, K., Kertis, M., Uoker, M., \& Hoffman, B., Romanov, B.K. (Ed.). (2012). Integrirovannaya farma- економіки, науки, освіти, практики : IV Міжнар. наук.практ. Internet-конор. (Харків, 24-25 берез. 2016 р.) : зб. наук. ст. - Харків : НФаУ, 2016. - С. 362-363.

13. Shmatenko O. P. Marketing analysis of the drugs used for the treatment of affected military men with brain injuries [Text] / O. P. Shmatenko, A. M. Solomenny, O. V. Pleshkova // Вісник фрармації. - 2014. - № 1 (77). C. $58-62$.

14. Державний реєстр лікарських засобів Україн [Електронний ресурс]. - Режим доступу : http://www. drlz.com.ual.

15. Компендиум: справочник лекарственных средств on-line [Электронный ресурс]. - Режим доступа: http://compendium.com.ua. kologiya [Integrated pharmacology]. Moscow: Logosfera [in Russian].

9. Hudzenko, O.P., \& Kuldyrkaieva, K.V. (2009). Marketynhovyi analiz vitchyznianoho rynku antyhemorahichnykh preparativ [Marketing analysis of the domestic market of antihemorrhagic drugs]. Visnyk farmatsii Journal of Pharmacy, 4 (60), 64-67 [in Ukrainian].

10. Kuldyrkaieva, K.V. (2009). Intehrovanyi AVS/ VEN/ chastotnyi analiz spozhyvannia hemostatychnykh likarskykh zasobiv v ramkakh rehionalnoho rynku [Integrated frequency analysis of consumption of hemostatic drugs within the regional market]. Ukrainskyi medychnyi almanakh - Ukrainian Medical Almanac, 12 (5), 105-107 [in Ukrainian].

11. Kutsenko, S.A., Malyi, V.V., Olkhovska, A.B., \& Maslii, Yu.S. (2016). Marketynhovi doslidzhennia vitchyznianoho rynku antyhemorahichnykh likarskyhh zasobiv [Market research of antihemorrhagic domestic market drugs]. Social Pharmacy in Health Care, 2 (3), 65-74 [in Ukrainian].

12. Yarnykh, T.H., Ruban, O.I., \& Olkhovska A.B. (2016). Analiz asortymentu antyhemorahichnykh likarskykh zasobiv na vitchyznianomu farmatsevtychnomu rynku [Analysis of assortment of antihemorrhagic medicinal products in the domestic pharmaceutical market]. Menedzhment ta marketynh u skladi suchasnoi ekonomiky, nauky, osvity, praktyky: zb. nauk. st. IV Mizhnar. nauk. -prakt. Internet-konf. - Management and marketing as a part of the modern economy, science, education and practice: Collection of Scientific articles of IV International scientific and practical Internet-conferences. Kharkiv: NfaU [in Ukrainian].

13. Shmatenko, O.P., Solomenny, A.M., \& Pleshkova, O.V. (2014). Marketing analysis of the drugs used for the treatment of affected military men with brain injuries. Visnyk farmatsii - Journal of Pharmacy, 1 (77), 58-62.

14. Derzhavnyi reiestr likarskykh zasobiv Ukrainy [The State Register of medicines of Ukraine] http://www. drlz.com.ua/ [in Ukrainian].

15. Kompendium: spravochnik lekarstvennykh sredstv on-line. [Compendium: reference book of medicines] http://compendium.com.ua. [in Russian]. 


\section{АНАЛИЗ АССОРТИМЕНТА ЛЕКАРСТВЕННЫХ СРЕДСТВ ГЕМОСТАТИЧЕСКОГО ДЕЙСТВИЯ}

\section{Резюме}

Вступление. Учитывая изменчивость фрармацевтического рынка, экономической и политической ситуации в стране, анализ ассортимента антигеморрагических лекарственных средств позволяет выявить фракторы, влияющие на оказание фрармацевтической помощи больным, и направления улучшения фризической и экономической доступности препаратов данного сегмента.

Цель исследования - изучить ассортимент антигеморрагических средств, которые представлены на отечественном фрармацевтическом рынке, и выявить место препаратов растительного происхождения.

Методы исследования. Ассортимент лекарственных средств и динамику продажи изучали с помощью доступных электронных ресурсов и аналитических систем.

Результати и обсуждение. Определено, что структура ассортимента сорормирована лекарственными средствами группы В02 “Антигеморрагические средства”. Анализ зарегистрированных лекарственных препаратов по отдельному действующему веществу показал, что в этой группе максимальную долю составляют средства, которые содержат фракторы свертывания крови и транексамовую кислоту. Установлено страны, экспортирующие на украинский фрармацевтический рынок антигеморрагические лекарственные средства. Определено основных отечественных производителей исследуемого ассортимента лекарственных средств. При сегментации рынка препаратов по лекарственным фрормам установлено преимущество парентеральных фрорм. Антигеморрагические лекарственные средства растительного происхождения занимают лищь 12,5 \% от общего ассортимента.

Вывод. Проведенные исследования дают основания утверждать, что разработка лекарственных препаратов на основе растительного сырья кровоостанавливающего действия перспективна и необходима.

КЛЮЧЕВЫЕ СЛОВА: антигеморрагические средства; анализ ассортимента; фармацевтический рынок гемостатиков.

U. V. Karpiuk ${ }^{1}$, V. S. Kyslychenko²

O. BOHOMOLETS NATIONAL MEDICAL UNIVERSITY' ${ }^{1}, K Y I V$ NATIONAL UNIVERSITY OF PHARMACY², KHARKIV

\section{ANALYSIS OF THE ASSORTMENT OF MEDICINES WITH HEMOSTATIC EFFECT}

\section{Summary}

Introduction. Taking into account the variability of the pharmaceutical market of Ukraine, the economic and political situation in the country, the analysis of the assortment of antihemorrhagic medicines makes it possible to identify factors affecting the provision of pharmaceutical care and the direction of improving the physical and economic accessibility of the medicines of this sigment.

The aim of the study - to examine the assortment of antihemorrhagic drugs, which are presented on the domestic pharmaceutical market and to identify the place of herbal drugs.

Research Methods. The range of drugs and the dynamics of sales were studied with the help of additional electronic resources and analytical systems.

Results and Discussion. It was determined that the structure of assortment of medicines with hemostatic action was formed by the group B02 antihemorrhagic means. Analysis of registered drugs for the individual active substances showed that in this group the maximum proportion of products contain blood clotting factors and tranexamic acid. Countries that export antihemorrhagic medicines to Ukrainian pharmaceutical market were determined. The main domestic manufacturers of assortment of medicines with hemostatic action were also set. Segmentation of the market for medicines dosage forms, showed the advantage of parenteral forms. Antihemorrhagic herbal medicines occupy only $12.5 \%$ of the total assortment.

Conclusions. The conducted researches give grounds to assert about the prospects and necessity of development of herbal medicines with hemostatic action.

KEY WORDS: antihemorrhagic medicines; assortment analysis; pharmaceutical market of hemostatics.

Адреса для листування: У. В. Карпюк, Національний медичний університет імені О. О. Богомольця, б-р Т. Шевченка, 13, Київ, 01601, Україна, e-mail: uliana.karpiuk@gmail.com. 